\title{
Editorial
}

\section{Development at the Crossroads of Capital Flows and Migration: Leaving No One Behind?}

\author{
Annelies (E.B.) Zoomers $\mathbb{D}$ \\ Department of Human Geography and Planning-International Development Studies, Faculty of Geosciences, \\ Utrecht University, Princetonlaan 8a, Room 6.06, 3584 CB Utrecht, The Netherlands; e.b.zoomers@uu.nl \\ Received: 11 December 2018; Accepted: 13 December 2018; Published: 17 December 2018

\begin{abstract}
The aim of this special issue is to push forward the frontier of development studies by analysing local livelihoods from a 'flows of capital/people' perspective. In development studies, and especially in livelihood research, local development has long been defined in terms of local people's agency and the importance of capitals and capabilities. Over the last decade, however, the context of local development has undergone considerable change. Globalisation, in alternation with deglobalisation, has given rise to new and intensified flows and circulations: the total volume and the diversity of capital flows and flows of people have rapidly increased, often going hand in hand with flows of goods, knowledge and ideas. Rather than looking at local development in terms of local people having access to and control of local resources, we acknowledge the importance networked space and positionality. Local development opportunities are very much determined by translocal linkages-what is happening in other places, sometimes directly, as a result of flows of capital, goods, people and information. The various articles in this special issue contribute to a better understanding of the link between large-scale flows of capital/people and local development, focusing on questions such as: what kinds of mobilities are taking place and in which directions? What are the new geographies of development, and what are the consequences of the inflows and outflows of capital/people (including goods and ideas) for local development and achieving the various sustainable development goals? In analysing the link between different types of capital/people flows and inclusive development, each article in this special issue focuses on a particular type of flow of capital/people and its multiple impacts in terms of local livelihood development. Case studies focus on Sub-Sahara Africa (Ghana, Mozambique, Ethiopia, Senegal, Rwanda); Asia (Vietnam, Indonesia, India) and Latin America.
\end{abstract}

Keywords: Translocal development; globalization; capital flows; land grabbing; international migration; sustainable development; SDGs; Africa; Asia; Latin America

\section{Introduction}

The aim of this special issue "Development at the crossroads of capital flows and migration: leaving no one behind?" is to contribute to a better understanding of local development in a context of globalisation, exploring current patterns of flows of capital and flows of people in relation to local people's livelihood opportunities. In seeking ways to improve local livelihoods-and to achieve the sustainable development goals ('leaving no one behind') - we start from the idea that the future will very much depend on whether flows of capital and flows of people are moving in the right direction.

In development studies, and especially in livelihood research, local development has long been defined in terms of local people's agency and the importance of capitals and capabilities [1-3]. According to this approach, local people's livelihoods depend on their access to different kinds of capital: human capital (labour, e.g., migration) and natural capital (e.g., land) are important assets, 
as are financial capital and physical capital (which can be expressed in monetary terms), social capital (e.g., networks of friends and family) and cultural capital (knowledge, norms, values, etc.).

Over the last decade, however, the context of local development has undergone considerable change. Global landscapes are showing rapid transformations. Traditional North-South relations have given way to a more fragmented pattern in which there are South-South, South-North and North-South exchanges. Globalisation, in alternation with deglobalisation, has given rise to new and intensified flows and circulations: the total volume and the diversity of capital flows and flows of people have rapidly increased, often going hand in hand with flows of goods, knowledge and ideas. Focusing on the rapidly increasing capital flows, in addition to large-scale foreign and domestic investments for various purposes, there is also ODA money from traditional donors and money originating from the BRIC countries and new charities (such as the Bill \& Melissa Gates Foundation), as well as capital flows coming from a new community of social businesses and impact investors. Looking at the flows of people, we see that the volume of people on the move (ranging from economic migrants, refugees and internally displaced persons, to students, entrepreneurs, consultants and tourists) has rapidly increased. The global migrant population, which is currently estimated at approximately 215 million, is expected to reach around 400 million in 2050 (http:/ /www.iom.int/). It is estimated that the worldwide flows of remittances amounted to $\$ 429$ billion in 2016. In addition, migrants also play important roles as investors and in the transmission of knowledge and ideas.

Given the rapid transformations, flows and circulations of capital and people deserve a more central place in theorisation about development. Local development plays out not just in fixed settings, but is increasingly shaped by flows and circulations of capital and people, namely the ways people are attached to and participate in networks. Rather than looking at local development in terms of local people having access to and control of local resources, we acknowledge the importance networked space and positionality $[4,5]$. Local development opportunities are very much determined by translocal linkages-what is happening in other places-sometimes directly, as a result of flows of capital, goods, people and information. But even localities that are hardly integrated into the global networks through which dynamic processes of change are channelled and spread are indirectly affected. This is because their perspectives and relative positions vis-à-vis other localities may alter as a result of changing market prices, the valuation of resources and alternative opportunities for local people who are prepared to move. Given that impacts are not fixed in space-and projects to promote local development often come from people in distant places (investors, migrants, experts, etc.) - traditional notions of 'local' livelihoods are increasingly difficult to maintain. Given the current goal of leaving no one behind, and benefitting from new types of 'flow-driven' development, people need to be able to 'plug in', deal with 'the foreign' and jump on the right train $[4,6]$. There is a need for a conceptual update.

\section{Local Livelihoods in a Context of Large-Scale Capital Flows and Migration}

The aim of this special issue is to push forward the frontier of development studies by analysing local livelihoods from a 'flows of capital/people' perspective. As highlighted above, the world is full of different types of large-scale capital flows and flows of people that have direct implications for local peoples' opportunities to have decent lives. Even though they are often discussed in separate debates, it is interesting to look at capital flows and people flows in combination. Large-scale capital investment and migration are very much interconnected: places that attract capital often turn into poles of attraction for immigrants (people looking for new opportunities) and/or become places of expulsion, displacement and resettlement. In addition to the mentioned link between capital flows and migration/immigration, displacement and resettlement, diasporas (or individual migrants) often play a direct role by sending remittances, investing in their home communities (which are often close to cities), or opening the door for domestic and foreign investors and/or the mobilisation of new flows of commodities (trade), knowledge and ideas. 
The rapidly increasing flows of capital/people over the last decade have led to rapid changes in landscapes and local livelihood opportunities. Enormous amounts of capital have been invested in land for various purposes, and although this promotes economic growth it often goes hand with land grabbing, which restricts local people's access to common-pool resources (land, water, forests, etc.) and leads to enclosures and competing claims. Millions of hectares have been set aside for investments in real estate and urban infrastructures, leading to rapid urbanization-the emergence of megacities and new towns, the urbanisation of the countryside, often accompanied by fragmentation and gentrification (gated communities), displacement and resettlement. In addition, fuelled by concerns about food and biofuels, enormous investments have also been made in soy and oil palm, in addition to other monocrops such as sugarcane, cacao, coffee and banana. These investments in industrial monocrops [7-9] have resulted in a worldwide process of 'monocultivation', which often results in deforestation. Even though this might contribute to new opportunities (employment, income, etc.), the benefits (for some) often do not outweigh the total costs (especially not when taking into account bypassed populations, environmental costs, etc.). Becoming an out-grower or plantation worker is the way to benefit, but not everybody will be able to do so, and producing monocrops often makes producers more vulnerable (price and climate variability). Other examples of rapidly increasing large-scale capital flows are related to climate change: large-scale investments in nature conservation and REDD+ projects. Facilitated through multilateral funding for reducing forest emissions, thousands of forest emission projects are currently being implemented on large areas of land in countries with remaining forest frontiers. Even though local people are supposed to share the benefits (e.g., by providing ecological services), levels of remuneration are low and the cost of losing access to common-pool resources is often higher than the benefits. In addition to such reserves, investments in tourism or ecotourism and the construction of new resorts also contribute to the rapid expansion of 'no-go areas'. All over the world, beautiful and often vulnerable spots such as forests and beaches are owned or controlled by foreign investors and are no longer accessible to local groups. Finally, huge investment continue to be made in concessions for the exploitation of oil, gas, bauxite, etc. (in e.g., Mozambique, Peru, Indonesia, Zambia and Nigeria), in addition to other forms of mining. Such investments have contributed to landscape destruction, in close association with displacement and resettlement. In countries such as China, Vietnam, Brazil and Ecuador, large-scale investments are made in hydropower dams, often in the context of climate change mitigation (green energy), forcing local people to move or become resettled $[10,11]$. Local groups are at best compensated for their loss of land, but the amount they receive is in many cases not enough to rebuild their livelihoods in new locations.

Over the last decade, along with the free flow of capital in the global South (mainly from capital-rich countries such as the USA, Europe, China, Gulf states, BRIC, etc.), opportunities for local people from the global South to move in the direction of capital-rich places have become increasingly limited as a consequence of border walls and anti-migration policies [12]. European countries and the USA, in particular, have become less accessible than before owing to heavy investments in improved border control (e.g., Frontex operations in the European Union, and the building of walls in the United States to keep immigrants out). As a direct result of restrictive policies in the European Union and the United States, migration routes have lengthened and migrants spend longer periods en route, remain longer in transition regions and take greater risks. As a consequence, the role of people smugglers has increased. Migrants find themselves confronted with rising costs and are forced to earn extra money on the way in order to finance the final part of their journeys. Many get stuck en route; having shed their old identities, they stay temporarily as quasi-migrants at intermediate locations. They are forced to discontinue their journeys but often cannot return home because they are afraid of loss of face and have no way to repay the money that family members and friends lent them. Particularly migrants in transition regions often endure poor conditions and are vulnerable to exploitation [13] (p.145). Enhanced border controls have not reduced illegality or helped to solve the problems. At the same time, in the context of new 'migration deals', new capital flows are being 
mobilised to 'tackle' the root causes of migration (and preventing people from moving towards Europe). Besides international migration (which is dominant in policy debates), the bulk of migration is taking place 'silently' within countries, or between neighbouring countries, contributing to rapid urbanisation.

Large-scale flows of people and capital investments have direct consequences for local landscapes, that is, the emergence of new hubs-places where new investments/newcomers concentrate, which have direct implications for the livelihood opportunities of local groups. Investment/settlement hubs are often conflictive in the sense of generating competing claims between different groups, creating new opportunities for some (and attracting immigrants) while leading to the displacement of others and/or the forcing of certain groups to move and be resettled in other places. The inflow or outflow of capital (and more particularly large-scale investments in land or other natural resources) has enormous implications for the livelihood opportunities of local groups, and not only for the directly affected populations in the investment hub, because the effects travel in space, creating chains of translocal effects that also affect people in bypassed places: people are triggered to move away (and resettle in nearby or faraway places) or are confronted with the arrival of displaced groups. Flows of capital and flows of people are reshaping the world, leading to rapid transformations, especially in Africa, Asia and Latin America.

\section{Contributions to This Issue}

The various articles in this special issue all contribute to a better understanding of the link between large-scale flows of capital/people and inclusive development. Relevant questions are, for example, what kinds of mobilities are taking place and in which directions? What are the new geographies of development, and what are the consequences of the inflows and outflows of capital/people (including goods and ideas) for local development and achieving the various sustainable development goals? In analysing the link between different types of capital/people flows and inclusive development, each article in this special issue focuses on a particular type of flow of capital/people and its multiple impacts in terms of local livelihood development.

\subsection{Flows in Rural Development and Nature Conservation}

The first three articles focus on large-scale investments that are currently taking place in the rural sphere and are putting pressure on local people's access to land: large-scale investments in irrigation and in food production in Northern Ghana, respectively, and investments in nature conservation and reducing emissions from deforestation and forest degradation (REDD+) in Vietnam.

The starting point for the first article-'Agricultural Investments and Farmer-Fulani Pastoralist Conflict in West African Drylands: A Northern Ghanaian Case Study' (Soeters, Weesie and Zoomers [14]) —is the fact that in many countries in the global South, there is a push to drive agricultural modernisation processes through private sector investments. In West African drylands, the land concessions required for such agri-businesses are often negotiated through customary authorities and inject large amounts of money into localised rural systems with low cash bases. The article argues that such transactions serve to increase the area under crop cultivation on an inter-seasonal basis, as financial spill-overs allow farmers to purchase larger quantities of agricultural inputs and prepare larger tracts of land. Simultaneously, such direct and indirect cash flows result in larger local herd sizes and an increase in the number of locally owned cattle, as cash is exchanged for cattle, which are generally regarded as an interest-accruing, savings buffer. Larger herd sizes, in turn, attract Fulani pastoralists in search of employment as contracted herders for local cattle owners. Taking Integrated Water and Agricultural Development (IWAD) - a private sector, large-scale irrigation initiative in northern Ghana as a case study-as an example, the article argues that large-scale land acquisitions in West African drylands inevitably lead to an increase in conflict (or the risk thereof) between sedentary and Fulani pastoralists.

Second, in Roaming through the Maze of Maize in Northern Ghana. A Systems Approach to Explore the Long-Term Effects of a Food Security Intervention, Mangnus and van Westen [15] analyse 
the long-term consequences of business investments in the value chain of maize, using a 'causal loop diagram' to analyse how vertically-oriented value chain interventions interact with landscapes. The underlying idea of such investment projects is that this will help to make value chains more inclusive: connecting farmers to input and output markets and to sources of knowledge and technology will enhance their food security status. The authors focus on two agro-business companies in northern Ghana and explore the long-term consequences of interventions aimed at increasing the yield of maize and providing farmers with a market. They show that, despite short-term positive impacts on especially food supply and income, such interventions also trigger changes that may hamper food security in the long run. Due to the companies' investments and efforts, farmers in Sissala East are becoming more dependent on maize, and thus less flexible. Even though more maize is cultivated in Sissala East, this does not automatically mean that enough is available locally for consumption. A significant share of the maize grain needs of southern Ghana had to be met by northern markets, and the subsequent higher prices in Sissala East negatively affected food deficit and food purchasing. The authors show the importance of taking into account the various impact pathways (also for soil fertility etc.) before starting these types of interventions.

Third, in 'Ten Years of REDD+: A Critical Review of the Impact of REDD+ on Forest-Dependent Communities', Bayrak and Marafa [16] focus on the case of Vietnam, analysing the developmental outcomes of the 'Reducing Emissions from Deforestation and Forest Degradation program' (REDD+) by stressing the need for a systems approach. The paper provides an in-depth analysis of the impact of REDD+ on forest-dependent communities. Many studies confirm that such communities are not sufficiently involved in current REDD+ projects. Furthermore, the current and potential impacts of REDD+ on communities often disrupt local people's livelihoods strategies, and their institutions and socio-cultural systems, in various ways, such as unequal benefit sharing, food insecurity, the introduction of new powerful stakeholders, illegal land acquisition, unfair free prior and informed consent and the introduction of monoculture plantations. In order to make REDD+ contribute to local development, it is important to use a holistic approach, that is, to attempt to incorporate local communities' complex relationship with the natural environment, including traditional forest management systems, while also providing viable alternatives to the loss of agricultural land.

\subsection{Flows in Urban Development and Infrastructure Expansion}

After this, the attention shifts to the urban sphere, with three articles focusing on the huge investments made in real estate development and infrastructure expansion in Africa and Latin America. The first focuses on Latin America and sub-Saharan Africa, the second on Mozambique (Beira) and the third on Ethiopia and Bangladesh. These articles show how investments are causing the emergence of gated communities, resettlement and displacement-and how costs and benefits are unequally redistributed.

The paper 'All-Inclusiveness versus Exclusion: Urban Project Development in Latin America and Africa' (Klaufus, van Lindert, van Noorloos \& Steel [17]) scrutinises current processes of urban fragmentation, segregation and exclusion that result from the increasing flows of capital into gated communities, walled-off condominiums and similar exclusivist investment hubs in Latin America and sub-Saharan Africa. Gated community-like developments are growing and spreading to new areas. Although not all of the walled projects offer all-inclusiveness, all are based on the pre-selection of specific categories of residents. Moreover, all-inclusive urban developments are assuming new and more encompassing forms, such as 'gated cities'. Hence, socio-spatial inclusion and exclusion in the urban built environment are continuously transforming under the influence of investment capital (i.e., new urban investment flows and speculation), urbanistic concepts (e.g., different interpretations of safety and crime) and human mobilities. The focus on different case studies makes it clear that in Latin America, gated communities have a long history, but exclusionary developments are changing both in form and in implications. In Africa, research on gated communities has particularly focused on South Africa (where such communities have a longer history), but exclusionary developments are 
rapidly spreading across the continent, and will influence future real estate development and land markets. Based on such complementary experiences, this paper grapples with the question how these new all-inclusive developments influence the possibility of achieving inclusive and sustainable urban transitions, as advocated in Sustainable Development Goal 11 (SDG 11) and the New Urban Agenda.

This is followed by Sustainable Urbanisation on Occupied Land? The Politics of Infrastructure Development and Resettlement in Beira City, Mozambique (Shannon, Otsuki, Zoomers, Kaag [18]), which provides an empirical analysis of forced displacement and resettlement associated with infrastructure development in Beira city, Mozambique. In recent years, Beira has become the recipient of numerous investment flows from a range of international investors targeting the built environment. By analysing the micro political engagements associated with three infrastructure projects, based on extensive qualitative interviews, observations and document analysis, the authors demonstrate how each intervention has been associated with highly informal and divergent processes of forced displacement and resettlement. They argue that these land-related impacts have been annexed from debates on sustainable infrastructure development, and that they exhibit some fundamental differences from established resettlement research, and conclude by arguing that forced displacement and resettlement should be understood as a deliberate and systematic feature of urban infrastructure development, through which new social-spatial arrangements are created. This ultimately points to the emergence of a novel mode of fragmented urbanism within the context of urban development in Africa that poses new challenges to urban sustainability.

In the next paper-'Infrastructures as Catalysts: Precipitating Uneven Patterns of Development from Large-Scale Infrastructure Investments'-Rammelt [19] shows how infrastructure investments in developing regions might bring benefits to some, but that more attention needs to be paid to the distribution of benefits. This paper examines such distributional effects based on two cases: rural roads in Ethiopia and flood control systems in Bangladesh. In both cases, the infrastructures promote particular development patterns towards market-economic transformations and integration. In analysing the impact of road development, Rammelt draws a parallel with the role of a catalyst in a chemical reaction: rural roads catalyse flows of agricultural labour, while flood control catalyses agricultural productivity. Taking the analogy a step further, the effects of a catalyst are known to vary due to the presence of so-called inhibitors and promoters. Applying this to the two cases, the paper shows that infrastructure often produces uneven patterns of development. Pre-existing conditions enable some groups to benefit while preventing other groups from doing so, and yet others are even worse off. The benefits of roads and/or flood control are distributed according to existing patterns of land ownership (are people capable of producing?) and/or whether they have access to motorised transport. Such 'local factors' represent significant promoters or inhibitors that can help to explain the unequal distribution of benefits, which often exacerbates inequalities. Investing in infrastructure has profound impacts on local economies and livelihoods. Given the enormous amounts currently being spent in Ethiopia, revisiting the redistributive effects is more relevant than ever.

\subsection{Flows of Knowledge and Ideas}

After this, the focus shifts to investments in knowledge institutes and/or for cultural and educational purposes, showing how flows of investments promote student mobilities and the dispersion of worldviews and ideas.

In the paper titled 'China's Confucius Institute in Indonesia: Mobility, Frictions and Local Surprises', Theo and Leung [20] show how China's cross-border language-promotion body-the Confucius Institute $(\mathrm{CI})$ - has proliferated along with the mobility of Chinese capital and people worldwide. It embodies the 'Going Out' state strategy that promotes the global spread of Chinese capital, ideas, culture and people. Often seen as a vehicle of China's power and influence, the CI has attracted much suspicion and even rejection, unlike the similar institutions of other states. This paper examines the mobility of the $\mathrm{CI}$ and the frictions encountered when it lands in particular places, problematising the commonly assumed unidirectional impact of the cross-border institution as a mighty 
soft-power instrument. Specifically, it analyses the frictions associated with the CI's establishment in Indonesia, where racial and political narratives on China and Chinese-Indonesians have long prevailed. Three cases are presented: one at the national level in Jakarta and two at the local level in the cities of Bandung and Makassar. By elaborating how frictions are created, resisted and managed differently, the paper illustrates the interplay of actors and power relations in the mobility of the CI, which leads to particular local 'surprises'. The paper also underlines the role of the Chinese-Indonesian diaspora as important bridge-builders of their two homelands.

This is followed 'Linking-In through Education? Exploring the Educational Question in Africa from the Perspective of Flows and (dis) Connections' [21]. According to Kaagits author, education, which is one of the most important gateways for inclusive development, is often interpreted in terms of its technical aspects, namely furthering skills and knowledge and strengthening human capital to promote development. By contrast, this paper focuses less on this technical aspect and instead analyses the current educational landscape in Africa as a field in which flows of investment, ideas and people influence connections between Africans and the rest of the world. As an effect of the structural adjustment programmes of the 1980s, public spending on education in many African countries went down, allowing private education initiatives to spring up. These were largely financed by Western and Arab countries. Over the last 15 years, investment flows into education from emerging global powers like China, Brazil, Malaysia and Turkey have contributed to an increasingly diversified educational landscape in Africa. This paper argues that these investments not only allow Africans to improve their educational levels but that these diverse forms of education also have an influence on connections and social orientations in African societies. Educational programmes go together with specific worldviews. In addition, people develop their social networks through educational trajectories. Both orientations and connections influence people's choices and opportunities in their further lives, and thus individual and societal development. Interestingly, investments in education by external parties are often not isolated endeavours, but are also used as a means to get linked-in in local societies for such diverse purposes as religion or business interests. Illustrating her argument with examples taken from her research on Gulf charities and on Turkish schools in Africa, Kaag explores how the new connectivities that come with the changing educational landscape in Africa shape actual and possible local development trajectories in the current era of intensified globalisation characterised by intensified flows of capital, people and ideas.

\subsection{Flows of People? Those Who Go and Those Who Remain}

The final three articles focus on the consequences of flows of capital/people from a more human perspective, analysing how migration generates multiple impacts, not only for 'those who move' (and people in destination areas) but also for those who remain or are left behind.

In 'Livelihood Trajectories in a Context of Repeated Displacement: Empirical Evidence from Rwanda', Cottyn [22] focuses on the long-term impact of repeated displacement, forced migration and resettlement in the case of Rwanda (one of the countries in Africa with a long history of multiple displacements). The life trajectories of many Rwandans are characterised by multiple experiences of involuntary migration and resettlement. Instead of treating each displacement separately, this article analyses the effects of repeated displacement, showing the importance of social and human capital for people's resilience and ability to reconstruct their livelihoods in new places. Looking at the interplay between various livelihood capitals substituting for the loss of natural resources (access and ownership of land), two types were found to be crucial to people's adaptive capacity: social capital in the form of horizontal connections, family support through remittances and community solidarity; and the use of human capital in the form of entrepreneurial skills and household members who are able to work. However, in the long run, the successive loss of natural capital in combination with changing social and economic conditions diminishes the ability of many households to keep employing these capitals to reconstruct a sustainable livelihood. Forced to become increasingly creative and flexible in their 
coping strategies, it is especially the displaced households that become increasingly dependent on migration. Many households employ mobility as a survival mechanism to spread risks.

Responses to repeated displacements and involuntary resettlements, paired with the successive loss of productive resources, need to acknowledge that the reconstruction of livelihoods does not always take place in fixed settings, but is shaped by the way people are attached to and participate in networks. When access to natural capital cannot be guaranteed or is not sufficient, supporting structures to facilitate the use of other capitals and assets to promote diversification are crucial.

In 'Rethinking Rural-Urban Migration and Women's Empowerment in the Era of the SDGs: Lessons from Ghana', Pickbourn [23] focuses on flows of women who migrate within national borders in Africa. According to Pickbourn, these flows have been largely ignored in contemporary conversations about migration, partly because internal migration, and particularly rural-urban migration, has been viewed in a negative light in development theory and praxis. This leads to the perception that women who migrate within national borders are worse off than they would have been otherwise, and to a policy stance that seeks to discourage their migration. Drawing on field research in Ghana, she argues that while rural-urban migration gives women access to an independent source of income, the emancipatory potential of migration for women is limited by the official stance towards rural-urban migration and informality. Nevertheless, the decision by women to migrate represents an attempt to improve their life outcomes and those of their families in the face of severely constrained options for doing so. Sustainable Development Goal 5 (SDG 5) - promoting gender equality and women's empowerment-requires a different approach to women's internal migration. Rather than seeking to constrain women's mobility, policy and programme interventions should be geared towards expanding their freedom to choose whether to migrate, by expanding the options available to women who stay at home as well as improving migration outcomes for those who migrate.

Finally, in 'They had to Go': Indian Older Adults' Experiences of Rationalising and Compensating the Absence of Migrant Children', Bailey, Hallad and James [24] argue that in transnational families, it is often the older adults who are left behind or choose to stay behind. The population aged 60 years or older in India currently constitutes over 7 per cent of the total population ( 1.25 billion) and this figure is projected to triple in the coming four decades. In the past, family was the major source of support in later life. One of the consequences of increased mobility is the decreasing role of family in care provision. The Indian middle-class norms on higher education, which stressed engineering and medicine, have resulted in professionally educated children leaving the parental home to seek work and thus family life in other geographical locations. In this paper, the authors examine how transregional and transnational mobilities and the resulting absences impact the lives of older adults. They draw upon 37 in-depth interviews conducted in Dharwad district of Karnataka, India. The results show that older adults employ two strategies: they rationalise the absence of migrant children and they compensate for that absence. These strategies reflect the resilience of the older adults to make sense of this trans-local family life-a life that previous generations were not aware of.

\section{Final Reflections}

The various articles show how globalisation has given rise to new and intensified flows and circulations, shaping places, development trajectories and livelihood possibilities in multiple ways. Evaluating whether capital investments/migration are contributing to inclusive development shows the need to move away from traditional space-bound assessment of 'local' development that derives conclusions about the extent to which 'local' populations may have improved their situations. 'Local' features-resources, populations, etc. - can no longer be viewed as separate and delineated entities (as is often done in project evaluations). Localities hardly ever stand by themselves. Positive impacts on a given locality might have negative implications for the situation in other places and for other people. In assessing whether certain interventions contribute to inclusive development, the 'travelling of development effects' should be taken into account: a change in one place (or sector) will affect others. When localities attract new investments and conditions of life really improve, it is not necessarily the 
'local' population that benefits: locals might be bypassed by new groups, or investments may trigger new patterns of migration that have implications for yet other localities that will now experience out-migration. Conversely, in the case of a dying locality, any attempt to slow or to stop the outflow of the population will also have implications for interconnected localities [25]. Development at the local level should be viewed as a sequence of interrelated changes. This is often not the common practice in project management ('theories of change' are often linear and project area-based).

Given the importance of flows of capital/people, the question whether people are capable of benefiting from globalisation cannot be understood in terms of 'local' people's agency, freedoms [26] or having access to 'locally bound assets'. Opportunities for local livelihood improvement depend very much on local people's capacity to link up with the right networks; their capacity to protect and/or compete; their ability to make timely decisions; and their power to influence decisions made by investors and/or migrants living in distant areas [4,6]. Wellbeing is also increasingly about whether people are capable of dealing with extremes and the unexpected, not only in response to climate variability, but also socially and economically.

In conclusion, development is increasingly coming from the outside. Understanding the complex links between 'locals' (or 'natives'), outsiders (or 'foreigners', including new categories of returnees), 'those who move' and 'those who remain' is a sine qua non for realising inclusive development and 'leaving no one behind'.

Funding: This research received no external funding.

Conflicts of Interest: The author declares no conflict of interest.

\section{References}

1. Bebbington, A. Capitals and capabilities: A framework for analyzing peasant viability, rural livelihoods and poverty. World Dev. 1999, 27, 2021-2044. [CrossRef]

2. Haan, L.; Zoomers, A. Exploring the frontier of livelihoods research. Dev. Chang. 2005, 36, 27-47. [CrossRef]

3. Kaag, M.; van Berkel, R.; Brons, J.; de Bruijn, M.; van Dijk, H.; de Haan, L.; Nooteboom, G.; Zoomers, A. Poverty Is Bad: Ways Forward in Livelihood Research; Interuniversity Research School for Resource Studies for Development CERES: The Hague, The Netherlands, 2004.

4. Zoomers, A.; Leung, M.; Westen, G. Local development in the context of global migration and the global land rush: The need for a conceptual update. Geogr. Compass 2016, 10, 56-66. [CrossRef]

5. Sheppard, E. The spaces and times of globalization: Place, scale, networks, and positionality. Econ. Geogr. 2002, 78, 307-330. [CrossRef]

6. Zoomers, A.; Otsuki, K. Addressing the impacts of large-scale land investments: Re-engaging with livelihood research. Geoforum 2017, 83, 164-171. [CrossRef]

7. Borras, S.; Franco, J.C. Towards Understanding the Politics of Flex Crops and Commodities. Implications for Research and Policy Advocacy; Think Piece Series On flex Crops and Commodities; Transnational Institute: Amsterdam, The Netherlands, 2014.

8. Budidarsono, S.; Susanti, A.; Zoomers, E.B. Oil Palm Plantations in Indonesia: The Implications for Migration, Settlement/Resettlement and Local Economic Development; INTECH Publication: Reijka, Croatia, 2014.

9. Cotula, L. The international political economy of the global land rush: A critical appraisal of trends, scale, geography and drivers. J. Peasant Stud. 2012, 39, 649-680. [CrossRef]

10. Pham Huu, T. Dilemmas of Hydropower Development in Vietnam: Between Dam-Induced Displacement and Sustainable Development. Ph.D. Thesis, Utrecht University, Eburon, The Netherlands, 2015.

11. Tanner, T.; Allouche, J. Towards a New Political Economy of Climate Change and Development. IDS Bull. 2011, 42, 1-14. [CrossRef]

12. Adepoju, A.; van Naerssen, T.; Zoomers, A. International Migration and National Development in Sub-Saharan Africa. Viewpoints and Policy Initiatives in the Countries of Origin; Brill Publishers: Leiden, The Netherlands, 2008.

13. Collyer, M. Undocumented sub-Saharan African migrants in morocco. In Mediterranean Transit Migration; Nyberg Sørensen, N., Ed.; Danish Institute for International Studies, DIIS: Copenhagen, Denmark, 2006; pp. 129-146. 
14. Soeters, S.; Weesie, R.; Zoomers, A. Agricultural investments and farmer-Fulani pastoralist conflict in West African drylands: A Northern Ghanaian case study. Sustainability 2017, 9, 2063. [CrossRef]

15. Mangnus, E.; van Westen, A. Roaming through the maze of Maize in Northern Ghana. A systems approach to explore the long-term effects of a food security intervention. Sustainability 2018, 10, 3605. [CrossRef]

16. Bayrak, M.; Marafa, L. Livelihood implications and perceptions of large scale investment in natural resources for conservation and carbon sequestration: Empirical evidence from REDD+ in Vietnam. Sustainability 2017, 9, 1802. [CrossRef]

17. Klaufus, C.; van Lindert, P.; van Noorloos, F.; Steel, G. All-inclusiveness versus exclusion: Urban project development in Latin America and Africa. Sustainability 2017, 9, 2038. [CrossRef]

18. Shannon, M.; Otsuki, K.; Zoomers, A.; Kaag, M. Sustainable urbanization on occupied land? The politics of infrastructure development and resettlement in Beira City, Mozambique. Sustainability 2018, 10, 3123. [CrossRef]

19. Rammelt, C. Infrastructures as catalysts: Precipitating uneven patterns of development from large-scale infrastructure investments. Sustainability 2018, 10, 1286. [CrossRef]

20. Theo, R.; Leung, M. China's Confucius Institute in Indonesia: Mobility, frictions and local surprises. Sustainability 2018, 10, 530. [CrossRef]

21. Kaag, M. Linking-in through education? Exploring the educational question in Africa from the perspective of flows and (dis) connections. Sustainability 2018, 10, 496. [CrossRef]

22. Cottyn, I. Livelihood trajectories in a context of repeated displacement: Empirical evidence from Rwanda. Sustainability 2018, 10, 3521. [CrossRef]

23. Pickbourn, L. Rethinking rural-urban migration and women's empowerment in the era of the SDGs: Lessons from Ghana. Sustainability 2018, 10, 1075. [CrossRef]

24. Bailey, A.; Hallad, J.; James, K. 'They had to Go': Indian older adults' experiences of rationalizing and compensating the absence of migrant children. Sustainability 2018, 10, 1946. [CrossRef]

25. Zoomers, A.; van Westen, A.C.M. Translocal development, development corridors and development chains. Int. Dev. Plan. Rev. 2011, 33, 377-388. [CrossRef]

26. Sen, A. Development as Freedom; Oxford University Press: New York, NY, USA, 1999.

(C) 2018 by the author. Licensee MDPI, Basel, Switzerland. This article is an open access article distributed under the terms and conditions of the Creative Commons Attribution (CC BY) license (http://creativecommons.org/licenses/by/4.0/). 